mittee on the Status of Endangered Wildlife in Canada. Canadian Wildlife Service. Ottawa, Ontario. 43pp.

${ }^{3}$ McLOED, J.A. 1943. Report on the crowduck menace on Lake Winnipegosis. Man. Dept. of Nat. Res. Fisheries Br. Wpg. $17 p p$.

${ }^{4}$ MCLOED, J.A. 1954. Continued studies on the double-crested cormorant on Lake Winnipegosis for the years 1953 and
1954. Man. Dept. of Nat. Res. Fisheries Br. Wpg. 9pp.

${ }^{5}$ VERMEER, K. 1969. The present status of double-crested cormorant colonies in Manitoba. Blue Jay 27: 217-220.

${ }^{6}$ VERMEER, K. 1970. Large colonies of caspian terns on Lake Winnipeg and Winnipegosis, 1970. Blue Jay 28:117118.

\title{
AN EASTERN WOOD PEWEE NEAR BETHUNE
}

CHRISTOPHER I. G. ADAM, 2636 Argyle Street, Regina, Saskatchewan. S4S OK1

On 3 July 1981, an Eastern Wood Pewee (Contopus virens) was encountered in the Qu'Appelle Valley 14 kilometres south of Bethune, Saskatchewan, by the author and Keith Neufeld, during investigations of natural areas for Saskatchewan Environment. The bird was first heard singing in late morning by the author, who immediately identified it as an Eastern Wood Pewee. The bird was approached to within $15 \mathrm{~m}$, photographed, and was observed singing for 20 minutes. The author is familiar with the song of this eastern species, having lived for several years in eastern Canada, and had in fact heard one as recently as 28 June 1981 in Manitoba.

The pewee had a pale breast with light gray sides and a yellowish wash towards the belly, a pale throat, and an orange lower mandible, in contrast to the darker Western Wood Pewee (Contopus sordidulus). The song was the typical, whistled "pee-ah-wee, pee-ahwee, pee-urr", constantly repeated. The pewee was still singing when the observers left the area around noon. The weather was hot and sunny.
Bob Luterbach of Regina had no luck finding the pewee at the same place at 0630 the next morning. The author is satisfied the location was revisited since Luterbach's description corresponded perfectly.

The pewee was found in a Manitoba Maple (Acer negundo) grove at the south end of an intermittant slough and near a gravel pit on the Qu'Appelle Indian Burial Site, an IBP (International Biological Program) area bordering the southern slope of the Qu'Appelle River. The exact location of the sighting is Sec. 2 - Twp. 19 - Rg. 24 - W2, which is approximately 45 kilometres northwest of Regina.

The bird was undoubtedly a summer visitant, probably having found its way westwards along the Qu'Appelle Valley. Belcher ${ }^{1}$ and Callin ${ }^{2}$ cite several occurrences in Saskatchewan. It is suspected as breeding regularly along the Qu'Appelle Valley as far west as Echo Lake. ${ }^{2}$ One was heard calling 11 May 1968 by A. Binnie near Flying Creek, north of Regina. ${ }^{2}$ 
'BELCHER, M. 1980. Birds of Regina, revised edition. Saskatchewan Nat. Hist. Soc. Spec. Publ. 12, Regina, Sask.

${ }^{2}$ CALLIN, E. M. Birds of the Qu'Appelle, 1857-1979. Saskatchewan Nat. Hist. Soc. Spec. Publ. 13, Regina, Sask.

\section{BIRD NOTES FROM SPRING VALLEY}

FLOSSIE BOGDAN, Box 92, spring Valley, Saskatchewan. SOH 3XO

Townsend's Warbler -12 miles S.E. of Spring Valley

On 5 September 1981 an overcast day, with light rain and drizzle with the sun peeking through once in a while, I was in the kitchen preparing lunch when I heard what sounded like a bird hitting the living room window. I went to check and saw a bird lying beneath the window. The bird was sort of olive green with the brightest of yellows. I rushed out to get it before the cats would. It was a warbler I had never seen before - so to the books I went. I took "Birds of North America" (Robbins, Bruun, Zim and Singer) and with the bird in my hand I walked over to my son's house. Together Larry and I identified the bird as an immature Townsend's Warbler, by the dark cheek patch outlined by bright yellow and the very bright yellow throat.

I checked the "Saskatchewan check list" and "Birds of Regina" but found no mention of a Townsend's Warbler.

I placed the bird on a soft cloth in a box, about three hours later it was ready to fly, I took it to the garden and put it on a head of a sunflower, said "good-bye" and watched as it flew to the trees. It was such a pretty little thing.

That evening after the busy day of butchering chickens I had time to think and I could have kicked myself. Why didn't we take some pictures? We had the bird in hand, but too late the bird was gone.

Had it been seen in a tree it would have been more difficult to identify, unless it posed for us.

Winter Wren - 12 miles S.E. of Spring Valley

Morning of 19 September 1980, I was out on my morning walk. As I approached a stand of willow trees a surprised little bird flew up from the underbrush of a mess of twigs overgrown with grass and weeds around the willows, it perched on a bare branch and gave out soft "tisks". I observed the kird for about 15 minutes before it disappeared under brush again. It was a tiny bird, with a short stubby tail and wrenlike actions, in the bright sunlight it appeared to be a rusty brown with an orange tinge to its breast.

Checking with "Birds of North America" (Robbins, Bruun, Zim and Singer) I identified it as a Winter Wren.

It was observed again the following day by daughter Gilbertha Leibelt, and myself - it again flew up from under the willows and perched on a dry twig.

Red-headed Woodpecker - 13 miles S.E. of Spring Valley

The afternoon of 16 July 1980 my son Allan phoned to let us know that there was a Red-headed Woodpecker at their trees, they have been watching it from their patio doors. I couldn't go just then but Larry and his wife Rhiannon went. By that time the Red-headed Woodpecker was on a power pole busy pecking away at something.

25 May 1980, 5 miles N.E. of Francis, Saskatchewan, my daughter, Gilbertha, looked out of her window and was surprised to see a Red-headed Woodpecker on their lawn, a furious 